\title{
Movement patterns of juvenile lemon sharks Negaprion brevirostris within Atol das Rocas, Brazil: a nursery characterized by tidal extremes
}

\author{
Bradley M. Wetherbee ${ }^{1, *}$, Samuel H. Gruber ${ }^{2}$, Ricardo S. Rosa ${ }^{3}$ \\ ${ }^{1}$ Department of Biological Sciences, University of Rhode Island, 100 Flagg Road, Kingston, Rhode Island 02881, USA \\ ${ }^{2}$ Division of Marine Biology and Fisheries, Rosenstiel School of Marine and Atmospheric Sciences, University of Miami, \\ 4600 Rickenbacker Causeway, Miami, Florida 33149-1098, USA \\ ${ }^{3}$ Departamento de Sistemática e Ecologia, CCEN, Universidade Federal da Paraíba, João Pessoa- PB, CEP 58059-900, Brazil
}

\begin{abstract}
Movement patterns and habitat use of juvenile lemon sharks Negaprion brevirostris were monitored at Atol das Rocas, Brazil, an atypical nursery area for this species, characterized by extreme tides and a lack of seagrass flats and mangroves. Twenty-three sharks carrying transmitters were monitored using an array of bottom-fixed automated receivers during 3 trips over a total of $60 \mathrm{~d}$. Transmitters were recorded on receivers over 13000 times, and the majority of sharks were detected more than 100 times. Newborn sharks (60 to $80 \mathrm{~cm}$ total length, TL) showed restricted but repeated movements between small tide pools on reef flats at low tide and a small, shallow, nearby tidal creek at high tide. Larger sharks (up to $106 \mathrm{~cm}$ TL) sampled 6 and 20 mo after the study in March 2000 frequented the tidal creek and several other locations at high tide and a variety of larger pools at low tide, and in general exhibited more extensive movements within the atoll than did newborn sharks. Sharks approaching $2 \mathrm{yr}$ of age were generally observed in specific pools or shallow water locations within the atoll during high and low tides, but also expanded their movements to include more of the atoll. Throughout the study, young lemon sharks appeared to concentrate movements within shallow-water low-tide refuges and separate high tidal areas. Movement patterns of sharks in Atol das Rocas differ from those at other well-studied lemon shark nursery locations, where individuals continuously occupy shallow flats and mangrove habitats. Nevertheless, lemon sharks in general restrict their movements to shallow-water habitats regardless of the specific nursery area occupied. This behavior is most likely related to predator avoidance. This study provides an example of the interaction between the physical environment and the biology of animals - in this case, the influence of the physical characteristics of a nursery area and the behavioral ecology of young lemon sharks.
\end{abstract}

KEY WORDS: Shark nurseries · Tidal fluctuation · Refuging · Movement patterns · Predator avoidance

\section{INTRODUCTION}

A fundamental tenet of ecology is the relationship between environmental variation and the subsequent variability in the biology of organisms, including their behavioral ecology (Ricklefs \& Miller 2000, Stiling 2002). Many marine fishes experience a variety of environmental conditions while utilizing shallow estu- aries and bays during the early stages of life. Fishes that inhabit these shallow environments are often subject to a rapidly fluctuating range of temperatures and salinities inherent to such shoreline locations. Many species of elasmobranchs also use shallow bays and estuaries as nursery grounds during the first years of their lives. These areas are thought to provide protection from predation because large predators in- 
frequently enter these areas (Castro 1993, Simpfendorfer \& Milwald 1993). The overall distribution and abundance of many elasmobranch species is closely tied to the availability of suitable nursery areas that support the survival and development of juveniles and sustained populations.

The lemon shark Negaprion brevirostris is an elasmobranch that uses nursery areas during the first few years of life, including some of the most extensively studied nurseries that exist for any species of shark (Sundstrom \& Gruber 1998, Gruber et al. 2001, Sundstrom et al. 2001, Feldheim et al. 2002). In particular, Bimini (the Bahamas) has been the site of numerous studies on activity patterns and habitat use of young lemon sharks (Gruber 1982, Gruber et al. 1988, Morrissey \& Gruber 1993a,b, Correia et al. 1995, Sundstrom et al. 2001). Young lemon sharks in the Bimini nursery largely confine their movements to shallow seagrass flats and shoreline mangroves, thus effectively reducing their exposure to potential predators (Morrissey \& Gruber 1993a,b). The shallow, seagrass flats and mangrove-lined lagoons that dominate the Bimini nursery are similar to habitat found at other intensely studied locations such as the Marquesas Keys, Florida, and other sites that have been identified as nurseries for this species throughout the Florida Keys, the Bahamas, and the Caribbean (Springer 1950, S. Gruber pers. obs.).

Atol das Rocas is a small atoll located $266 \mathrm{~km}$ off the coast of Natal, Brazil, and is thought to be the southern-most nursery area used by lemon sharks in the southwest Atlantic (Rosa \& Moura 1997, Silva et al. 2002). The physical characteristics of the nursery at Atol das Rocas differ in a number of respects from the more typical lemon shark nurseries that have been investigated in the Bahamas and Florida. Atol das Rocas is an oceanic atoll that is relatively isolated from other shallow water locations, contains no mangroves or seagrass flats, and is subject to an extreme tidal flux that renders much of the inner lagoon of the atoll devoid of water at low tide (Silva et al. 2002). The unusual characteristics of Atol das Rocas and access to this site during several cooperative Brazil-US research expeditions provided a unique opportunity to examine habitat use by lemon sharks in a nursery that differs substantially from other wellstudied nursery areas, and also to examine the behavior of sharks in a setting characterized by frequent changes in environmental conditions and the availability of habitat. The goals of this study were to (1) investigate activity patterns and habitat use of lemon sharks at an atypical nursery, Atol das Rocas, and (2) compare movement patterns of lemon sharks at Atol das Rocas with those of sharks within more typical nurseries.

\section{MATERIALS AND METHODS}

Study site. Atol das Rocas ( $\left.3^{\circ} 52^{\prime} \mathrm{S}, 33^{\circ} 49^{\prime} \mathrm{W}\right)$ consists of an oval shaped (approximately $2.5 \times 3.7 \mathrm{~km}$ ) reef of coralline algae, vermetid gastropods and coral, with a shallow, largely sand-covered central lagoon (Fig. 1). The proximity of the atoll to the equator results in the occurrence of relatively large tidal fluxes of up to $4 \mathrm{~m}$ between high and low spring tides within 1 tidal cycle. There are 2 small islands located along the western edge of the atoll, Cemetery and Farol Islands, which represent the only land remaining above water at high tide, other than several large volcanic boulders that surround the lagoon. Farol Island has a narrow peninsula along its southern margin that forms a narrow 400 to $500 \mathrm{~m}$ long tidal creek (Lama Bay) along the interior edge of the island. This small inlet is fully covered with water at high tide, but is essentially dry at low tide. The north side of the atoll contains a permanent channel (NE Channel or Barretão) to the open sea that extends several hundred meters into the interior of the atoll even at low tide. There are several other short channels leading from the perimeter of the atoll to the surrounding sea, including the NW Channel or Barretinha as well as Podes Crer and Salão along the southern margin of the atoll. At low tide, much of the lagoon floor and peripheral rock structure is above water, and numerous pools of various sizes are formed both within the central portion of the atoll and along the perimeter (Fig. 1).

Shark capture and instrumentation. This project was carried out during 3 research expeditions to Atol das Rocas during March and September 2000 and November/December 2001 (henceforth 'November 2001 ' trip). Lemon sharks were captured with dip net or gillnet in small tide pools or on the shallow flats. Upon capture, the sex, weight, and length (precaudal, fork and total length) of each shark were recorded. A coded passive integrated transponder (PIT, Destron/ Digital Angel) tag was implanted just beneath the skin below the first dorsal fin of each shark captured.

Acoustic transmitters (model V8B-2L R-R256 coded pingers, Vemco) were placed both externally and internally on sharks. The transmitters were small $(33 \times$ $9 \mathrm{~mm}$ ) and weighed approximately $3.5 \mathrm{~g}$ in water, less than $1 \%$ of the body weight of the sharks. These transmitters emitted an individually coded acoustic signal of $69 \mathrm{kHz}$ at random intervals varying between 60 and $180 \mathrm{~s}$, and had a nominal battery life of $60 \mathrm{~d}$. During the March 2000 trip, acoustic transmitters were attached to sharks by passing 2 short lengths of plastic-coated wire through the dorsal fin and around the 2 ends of the transmitter. During subsequent trips, acoustic transmitters were surgically implanted into the body cavity of each shark through a small $(3$ to $4 \mathrm{~cm}$ ) incision on its 


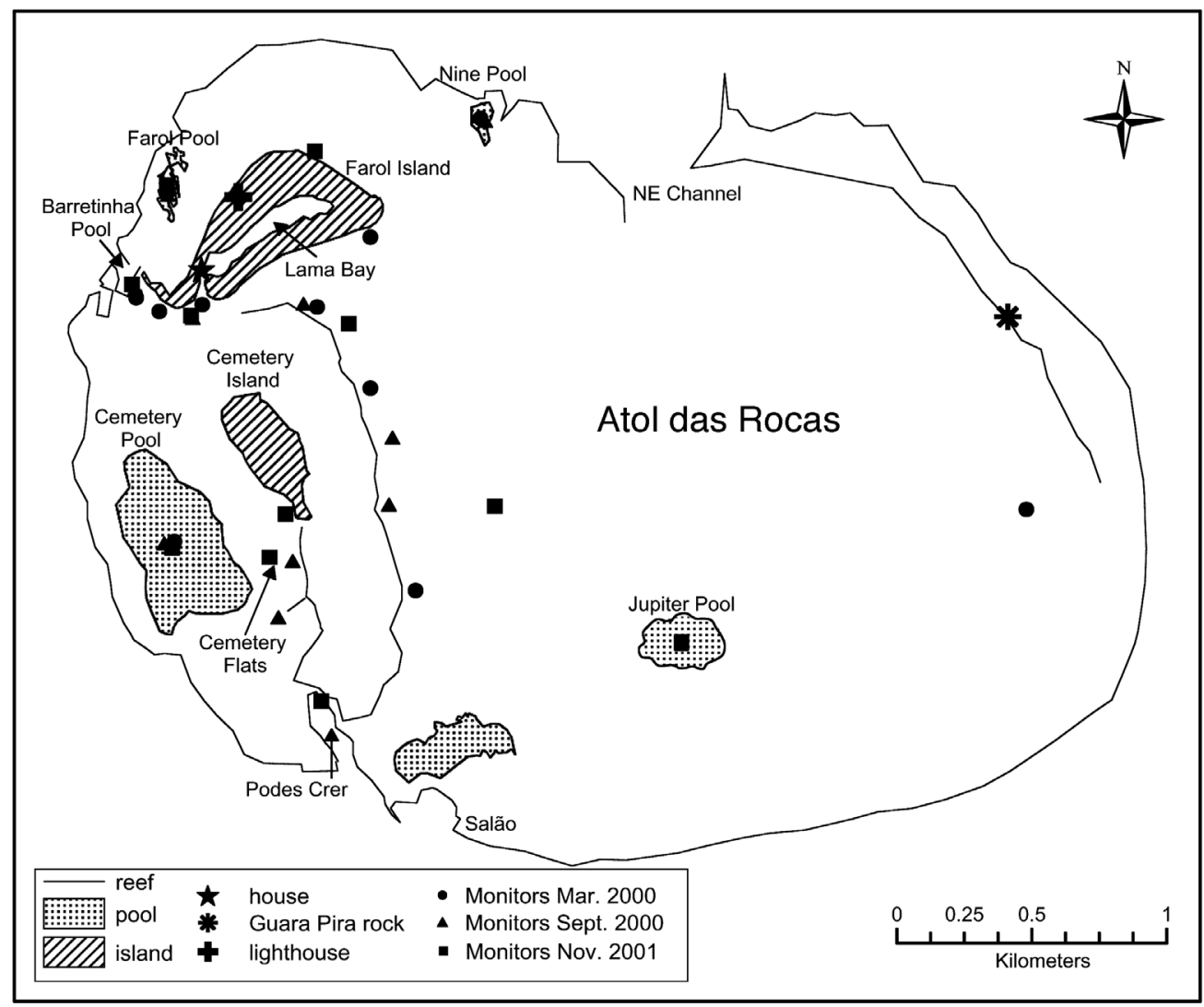

Fig. 1. Atol das Rocas $\left(3^{\circ} 52^{\prime} \mathrm{S}, 33^{\circ} 49^{\prime} \mathrm{W}\right)$, with locations of islands, major pools, and acoustic receivers during expeditions

ventral surface, just anterior to the pelvic fins. The incision was closed with monofilament sutures using a simple interrupted stitch (Wagner et al. 2000). Transmitters were coated with a mixture of paraffin and candle wax to reduce possible immune response to the presence of a foreign body within the sharks. Sharks were periodically immersed in the seawater pools during the procedure, which took approximately $10 \mathrm{~min}$. All sharks swam away vigorously upon release and subsequent acoustic detections, recaptures and visual observations showed that they recovered fully from the surgery. For 1 shark recaptured $3 \mathrm{wk}$ following the surgery, the sutures were no longer present and only a very faint scar remained where the incision had been made.

Twenty-three sharks (14 male, 8 female and 1 of unknown sex), ranging in size from 60.3 to $106.0 \mathrm{~cm}$ total length (TL), were captured, and a transmitter was either attached externally (March) or implanted into the body cavity (September and November) for each shark (see Table 2); 8 sharks were fitted with transmitters during each of the first 2 trips and 7 sharks during the third. All sharks captured in March 2000 were in the first few months of their lives and all but one were captured in a small tide pool (Barretinha Pool) near the NW Channel (Fig. 1). During September 2000, all but one shark were presumed to have been born approximately 7 to 9 mo earlier in the year based on the size of the individuals and estimated growth rates (Freitas et al. 2006). Compared with March, fewer sharks were observed in the small tide pools next to Farol Island, and it was necessary to capture additional sharks on shallow flats near Cemetery Island (see Fig. 1). In November 2001, sharks were even less concentrated in central locations and were caught at a variety of locations. During this trip, larger sharks were captured and all but one shark were presumed to be nearing 2 yr of age (Brown \& Gruber 1988).

Automated receivers (VR1 and VR2 models, Vemco) were used to monitor the presence of sharks carrying transmitters. Receivers recorded identification number, arrival time and departure time when the acoustic signal was within range of the receivers (see Voegeli et al. 2001). Detection range of individual receivers depended on location and tide level, and varied from a maximum of $500 \mathrm{~m}$ in larger pools or at high tide to a minimum of less than $50 \mathrm{~m}$ in small pools at low tide. Receivers were either suspended by stainless steel cables in mid-water between a cement block and a small float in areas continuously underwater, or attached with cable ties to a cement block in areas that were dry at low tide. An elec- 
tromagnetic couple was used to download data to a notebook computer every 3 or $4 \mathrm{~d}$ during each trip. Receivers were retrieved at the end of each trip.

The locations where receivers were deployed in March were based on suggestions from personnel that had worked extensively at Atol das Rocas and had observed small lemon sharks within the atoll. During the March trip, several receivers were moved to new locations because they had received no detections during the first week of deployment. During the September and November trips, sharks were much less common in Lama Bay and in the reef-flat tide pools, and the population of young sharks was less concentrated in these areas. Therefore, receivers were placed at more distant locations in an attempt to more fully monitor the movements of the sharks throughout a greater expanse of the atoll. Receiver locations for each of the 3 trips are shown in Fig. 1.

\section{RESULTS}

\section{Receivers and sharks}

Seven receivers were deployed at Atol das Rocas for a total of $60 \mathrm{~d}$ over 3 expeditions: $14 \mathrm{~d}$ during the first trip (March 2000) and 23 d during both the second (September 2000) and third (November 2001) trips. This resulted in nearly $1400 \mathrm{~h}$ of monitoring, approximately $312 \mathrm{~h}$ during the first trip and over $500 \mathrm{~h}$ during each of the 2 subsequent trips (Table 1). During the 3 trips, over 13000 individual transmitter 'pings' (emission of a coded acoustic signal) were recorded on receivers, nearly 8500 during the first trip and over 2000 during each of the last 2 trips. Movements of sharks among locations could therefore be inferred from their presence within the range of a particular receiver at a particular time (referred to as a 'detection'). Each detection therefore consisted of multiple 'pings' (or 'hits') from a transmitter received over a

Table 1. Dates, receiver coverage and total number of transmitter signals (hits) recorded during 3 trips to Atol das Rocas. High tide, low tide, mid-tide: no. of hits at respective tide

\begin{tabular}{|c|c|c|c|c|}
\hline & \multicolumn{2}{|c|}{2000} & 2001 & Total \\
\hline & 8-21 Mar & 11 Sep-3 Oct & 11 Nov-3 Dec & \\
\hline No. of receivers & 7 & 7 & 7 & 21 \\
\hline No. of days & 14 & 23 & 23 & 60 \\
\hline Coverage (h) & 312 & 518 & 528 & 1358 \\
\hline Hits recorded & 8499 & 2233 & 2352 & 13084 \\
\hline Hits $\mathrm{h}^{-1}$ & 27.2 & 4.3 & 4.5 & 9.6 \\
\hline High tide & 5488 & 493 & 497 & 6478 \\
\hline Low tide & 2166 & 1403 & 1025 & 4594 \\
\hline Mid-tide & 845 & 337 & 830 & 2012 \\
\hline
\end{tabular}

period of several minutes. The large number of transmitter pings on receivers allowed a conservative estimate of the presence of a shark in the vicinity of a receiver, because only multiple pings were interpreted as the actual presence of a particular shark at a particular location and time. This greatly reduced the possibly of false detections that may have resulted from sound sources other than transmitters. With the exception of 1 individual tagged at the end of the March trip, all sharks carrying transmitters were detected on receivers. The number of detections recorded for each shark ranged between 25 and 3973, with 19 individuals detected over 100 times and 4 sharks detected more than 1000 times (Table 2).

Despite the shorter duration of coverage during the first trip (only $23 \%$ of total monitoring hours), $65 \%$ of hits recorded during the entire study occurred during the March trip. Expressed on the basis of hits per hour, the high number of hits during March (27.2 hits $\mathrm{h}^{-1}$ ) is noteworthy in comparison with September (4.3 hits $\mathrm{h}^{-1}$ ) and November (4.5 hits $\mathrm{h}^{-1}$ ) (Table 1). During the entire study, the majority of detections were recorded within $2 \mathrm{~h}$ time blocks on either side of high tide $(49.5 \%)$ and low tide $(35.1 \%)$, indicating the efficacy of the receivers for monitoring the location of sharks during high and low tidal extremes (Table 1). These trends also demonstrate the reduced site attachment to Lama Bay and nearby reef-flat tide pools, and the need to (1) capture sharks at other locations during the second and third trips, and (2) expand the array of receivers to cover more of the atoll during these trips.

\section{March 2000}

Movement patterns exhibited during $14 \mathrm{~d}$ of observation were characterized by repeated short-distance movements between 2 small tide pools on the reef flats adjacent to Farol Island at the northwest perimeter of the atoll during low tide, and Lama Bay (the small tidal creek within Farol Island) at high tide (Fig. 1). The large number of detections on receivers at Lama Lagoon and the reef-flat tide pools are evidence of repeated, short-distance movements of newborn sharks between these 2 locations at the tidal extremes during the March trip. The very high number of detections on receivers at Lama Bay and nearby tide pools, near-constant detection of several sharks on receivers at these 2 locations over the $14 \mathrm{~d}$ monitoring period, and the paucity of detections on receivers located elsewhere all indicate that the sharks were highly site-attached to these high tide and low tide locations during March (Table 1). 
Table 2. Negaprion brevirostris. Sharks carrying transmitters in Atol das Rocas during March and September 2000 and November 2001: passive integrated transponder tag (PIT) number, tagging location and no. of times each shark was detected on receivers. (-) no data available

\begin{tabular}{|c|c|c|c|c|c|c|c|}
\hline PIT no. & Date tagged & Sex & $\mathrm{TL}(\mathrm{cm})$ & Weight (kg) & Location & Transmitter no. & No. detections \\
\hline \multicolumn{8}{|l|}{ March 2000} \\
\hline 4137064214 & 8 Mar & $\mathrm{F}$ & 60.3 & - & Barrentinha & 1 & 1031 \\
\hline- & $8 \mathrm{Mar}$ & - & - & - & Barrentinha & 2 & 108 \\
\hline $413701326 \mathrm{~F}$ & $8 \mathrm{Mar}$ & M & 66.4 & - & Barrentinha & 3 & 3973 \\
\hline $413675121 \mathrm{E}$ & $8 \mathrm{Mar}$ & $\mathrm{F}$ & 66.3 & - & Barrentinha & 4 & 237 \\
\hline $4136262 C 75$ & 8 Mar & $\mathrm{M}$ & 67.1 & - & Barrentinha & 5 & 1953 \\
\hline 4137042A4F & $8 \mathrm{Mar}$ & $\mathrm{F}$ & 64.6 & 1.5 & Barrentinha & 6 & 780 \\
\hline 4137085F29 & 8 Mar & M & 65.4 & 1.6 & Barrentinha & 7 & 417 \\
\hline 41370B3B3A & 19 Mar & $\mathrm{F}$ & 68.2 & 1.5 & Lama Bay & $7 b$ & 0 \\
\hline \multicolumn{8}{|c|}{ September 2000} \\
\hline 4137047320 & $10 \mathrm{Sep}$ & $\mathrm{M}$ & 79.4 & - & Farol Pool & 8 & 218 \\
\hline 4137056A22 & $10 \mathrm{Sep}$ & $\mathrm{F}$ & 79.4 & - & Farol Pool & 7 & 740 \\
\hline 4230452828 & 11 Sep & M & 98.4 & 4.9 & Cemetery Flats & 10 & 233 \\
\hline $4136262 \mathrm{C} 75$ & $11 \mathrm{Sep}$ & M & 80.4 & 2.5 & Cemetery Flats & 12 & 25 \\
\hline 42303E3723 & $12 \mathrm{Sep}$ & $\mathrm{F}$ & 76.0 & 1.6 & Cemetery Flats & 5 & 81 \\
\hline 4230436C20 & $12 \mathrm{Sep}$ & M & 71.0 & 1.5 & Cemetery Flats & 6 & 199 \\
\hline 4230444 E68 & $16 \mathrm{Sep}$ & $\mathrm{M}$ & 77.0 & 2.0 & Cemetery Flats & 13 & 196 \\
\hline 41370643371 & $16 \mathrm{Sep}$ & M & 78.0 & 2.3 & Farol Pool & 11 & 541 \\
\hline \multicolumn{8}{|c|}{ November 2001} \\
\hline 422F407C4E & $13 \mathrm{Nov}$ & M & 106.0 & 6.2 & Lama Bay & 2 & 228 \\
\hline 411C402A48 & $14 \mathrm{Nov}$ & M & 92.2 & 4.4 & Cemetery Flats & 3 & 100 \\
\hline 420E48044C & 17 Nov & M & 91.3 & 3.7 & Jupiter Pool & 1 & 277 \\
\hline $422 F 287956$ & $18 \mathrm{Nov}$ & $\mathrm{M}$ & 91.7 & 3.7 & Jupiter Pool & 4 & 481 \\
\hline 411C403A36 & $22 \mathrm{Nov}$ & $\mathrm{M}$ & 95.1 & 4.8 & Cemetery Flats & 5 & 1097 \\
\hline 411C41010E & $26 \mathrm{Nov}$ & $\mathrm{F}$ & 89.9 & 3.7 & Podes Crer & 6 & 133 \\
\hline 411C4E2840 & $27 \mathrm{Nov}$ & $\mathrm{F}$ & 75.4 & 2.0 & Farol Pool & 8 & 36 \\
\hline Total & & & & & & & 13084 \\
\hline
\end{tabular}

In the present study, our visual observations on multiple days during spring tides confirmed the behavior of lemon sharks that had been described to us by researchers working at Atol das Rocas. On numerous occasions, we observed 40 to 50 young-of-the-year lemon sharks aggregating at the narrow mouth of Lama Bay in the several hours prior to high tide. The sharks were clearly observed moving into Lama Bay as the tide rose, and were later observed in the recesses of the tidal creek during high tide. Owing to the narrowness of the bay entrance, and the clarity and shallowness of the water, sharks (including several carrying transmitters during the March trip) were easily observed at the entrance of the creek, moving into the creek and exiting Lama Bay as the tide receded. Previous investigators observed groups of nearly 100 lemon sharks demonstrating this same behavior, and these observers took advantage of these aggregations to capture large numbers of sharks at one time as the animals left Lama Bay with the receding tide (Oliveira 2001, Freitas et al. 2006). Additionally, no observations were ever made of sharks moving away from the mouth of the tidal creek following the beginning of the aggregation, even though such behavior would have been clearly visible owing to the clarity and shallowness of the water. The receiver at Lama Bay was also positioned a short distance into the narrow mouth of this tidal creek and had a limited range of detection. Therefore, based on the observations noted above, we are confident that this receiver served as a turnstile to detect movement of sharks into Lama Bay as the tide rose and their movement out of Lama Bay with the falling tide several hours later.

All instances (43 detections) of sharks recorded on a receiver during low tide in March 2000 occurred in one of the 2 reef-flat tide pools, Farol Pool and Barretinha Pool, which were the capture sites for all sharks carrying transmitters. Of the 57 high-tide detections, 54 were for sharks at the mouth of Lama Bay. Each shark carrying a transmitter (with the exception of 1 shark tagged during the last $3 \mathrm{~d}$ of monitoring) was recorded on receivers in either Lama Bay or 1 of the 2 reef-flat tide pools, and 5 of 7 sharks with transmitters were recorded repeatedly on receivers in both the reef-flat pools at low tide and in Lama Bay during high tide over the $14 \mathrm{~d}$ of monitoring.

Fig. 2 illustrates the repetitive pattern of movement between Lama Bay at high tide and the reef-flat tide 

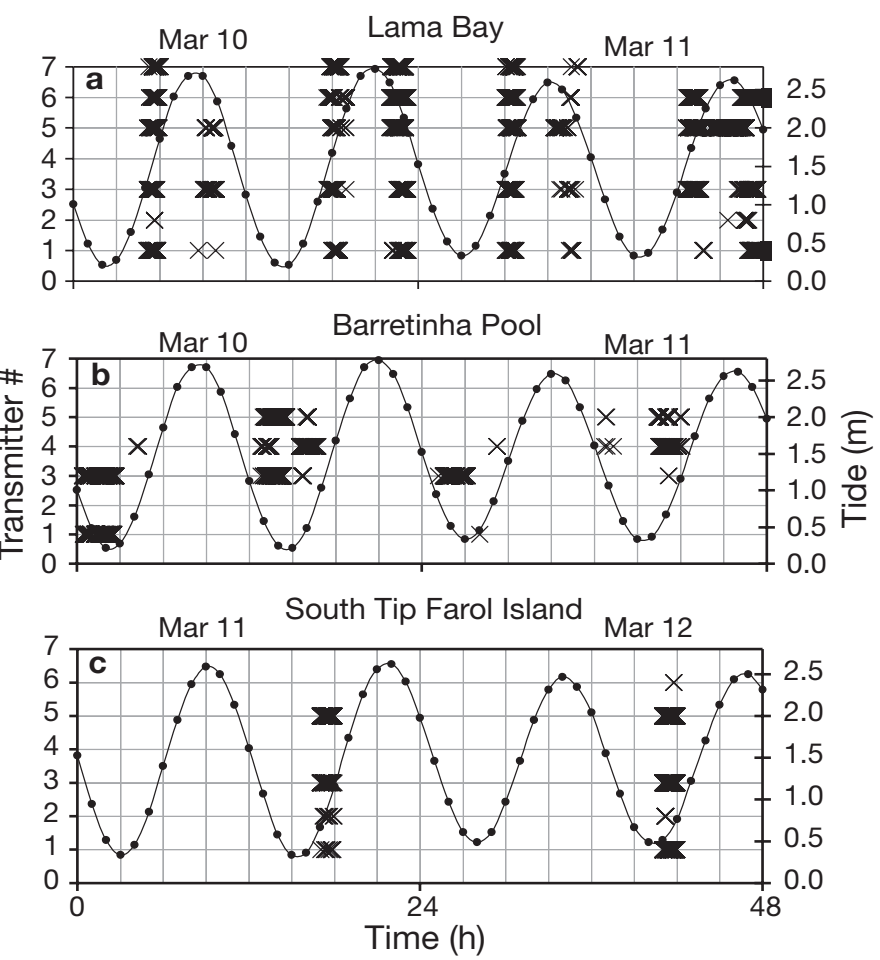

Fig. 2. Negaprion brevirostris. Record of acoustic signals from transmitters carried by Sharks 1 to 7 in March 2000. Each data point $(\times)$ represents an individual detection for 1 of 7 sharks in real time (Time $0=$ initial deployment of receiver array) over a $2 \mathrm{~d}$ period. Presence of sharks during different phases of the tidal cycle are shown for 3 locations: (a) Lama Bay, the entrance of the tidal creek, where the majority of detections occurred during rising and falling tides on either side of peak high tide; (b) Barretinha, a small pool on the reef flat in front of Farol Island, where the majority of detections occurred during low tide; (c) southwestern tip of Farol Island, where several individuals were detected during directed movement from reef-flat pools during low tide to Lama Bay during rising tides. Refer to Fig. 1 for locations

pools at low tide exhibited by newborn lemon sharks during March. The 1302 detections over a $2 \mathrm{~d}$ period shown in Fig. 2a are consistent with visual observations of the arrival of sharks at the entrance of Lama Bay with the rising tide, their milling about near the creek mouth and their gradual entrance into Lama Bay. The data presented in Fig. 2 are also consistent with movement of sharks past the receiver at the entrance of Lama Bay and into the recesses of the bay, where they were out of range of the receiver for several hours at peak high tide. Detections on the Lama Bay receiver shown in Fig. 2a are also consistent with repeated visual observations of a rapid movement of sharks out of the tidal creek as the tide started to fall.

Within several hours of the mass exodus of sharks from Lama Bay that was observed visually numerous times and supported by telemetry data, sharks began to be detected on receivers in Farol and Barretinha pools (Fig. 2b). Because of the limited size of the pools, sharks were often detected continuously while they remained in the pools (for 3 to $6 \mathrm{~h}$ ). As the tide rose and water began to cover the rocky flats surrounding the pools, the sharks began to leave the pools and within several hours were detected again at the entrance to Lama Bay (Fig. 2a). These movements were also confirmed by visual observations of the behavior of sharks in the small reef-flat tide pools as the tide rose.

The reef-flat tide pools and Lama Bay are within several hundred meters of each other, and essentially lie on opposite sides of Farol Island (Fig. 1). There is evidence based on both telemetry data and visual observation that the pathway of shark movements between Farol and Barretinha pools at low tide and Lama Bay at high tide was a fairly direct circuit around the southwestern perimeter of Farol Island. Newborn lemon sharks were observed swimming very close to shore along the southwest edge of Farol Island in the direction of Lama Bay during several rising tides. In an attempt to determine if sharks leaving the tide pools were making similar transits on their way to Lama Bay, a receiver was placed at the southwest tip of Farol Island, approximately equidistant between Barretinha Pool and the entrance to Lama Bay, over a $2 \mathrm{~d}$ period. Fig. 2c shows 659 hits recorded on this receiver. Of the 5 sharks detected at this site during the rising tide, 4 were recorded a short time earlier at either Barretinha or Farol pools at low tide and a short time later at the entrance to Lama Bay near high tide, demonstrating that sharks moved along a direct route around the southwest tip of Farol Island between the 2 tidal extreme locations. Sharks were detected on this receiver only on rising tides, and detections were not recorded during all tidal cycles in which the receiver was in place at the tip of the island. As the tide rises, water gradually spreads into the atoll and eventually the majority of the atoll becomes submerged. When the tide falls, strong and rapid currents develop within the atoll, and water drains from the tidal creek around the southwest edge of Farol Island, in a manner similar to that of a rapidly flowing river, in the direction of the reef-flat tide pools. Thus, young sharks exiting Lama Bay could ride a strong tidal current around Farol Island and reach the tide pools in a short time while expending very little swimming effort. There were also a number of records indicating that sharks did not always move directly between the reef-flat tide pools and Lama Bay, but instead occasionally spent as long as $1 \mathrm{~h}$ moving in shallow water along the edge of either Farol or Cemetery islands just prior to entering Lama Bay (on 7 occasions) or shortly after exiting the lagoon (10 occasions).

Three sharks were detected on receivers in the reefflat tide pools during low tide and in Lama Bay during 
high tide over the course of the entire $14 \mathrm{~d}$ monitoring period during March. For example, Shark 3 was detected on the Lama Bay receiver during high tide on 12 different days and in the nearby tide pools during low tide on 11 days. Additionally, Shark 5 was detected on the receiver at Lama Bay during high tide on 9 different days and in the tide pools during low tide on $11 \mathrm{~d}$.

The observation of nearly 50 sharks at the entrance of Lama Bay as high tide approached, but unquestionably fewer than 50 sharks in Barretinha and Farol pools at low tide, demonstrates that there were lowtide locations other than Barretinha and Farol pools used by small lemon sharks exiting Lama Bay. However, the repeated and systematic movement of sharks between reef-flat tide pools at low tide and Lama Bay at high tide appeared to be a typical pattern of movement for newborn lemon sharks that aggregate at the entrance of Lama Bay during the rising tide.

\section{September 2000}

Sharks monitored during September exhibited movement patterns similar to those of sharks monitored during March 2000. However, in September, sharks appeared to range greater distances within the atoll and movement patterns were less predictable than the repeated short-distance movements exhibited by sharks tracked during March. The dramatic decline in detections on receivers in Lama Bay and the nearby tide pools during September, coupled with an increased number of visual observations of young-ofthe-year sharks at other locations, suggests that sharks were less site-attached during September and frequently moved away from Lama Bay and nearby tide pools. Fewer sharks were observed both during high tides at Lama Bay and low tides in the reef-flat tide pools than during the March trip. As a result, 5 sharks were captured and equipped with transmitters on the shallow reef flats south of Cemetery Island, in addition to 3 captured at Farol Pool (see Table 2). These 2 groups of sharks differed somewhat in their movement patterns, but individuals belonging to both groups were regularly detected on the receiver in Lama Bay during high tide.

Several sharks captured in Farol Pool (Sharks 7, 8 and 11) were repeatedly detected on the receiver in Lama Bay just prior to or following high tide, and were again detected in Farol Pool during low tide, similar to patterns observed for sharks during March (Fig. 3). During the $23 \mathrm{~d}$ September 2000 trip, 30 of 31 locations for these individuals at or near high tide were recorded on the Lama Bay receiver. These sharks were detected even more consistently and over a greater span of time at Farol Pool, where the majority (45 of 51) of low-tide

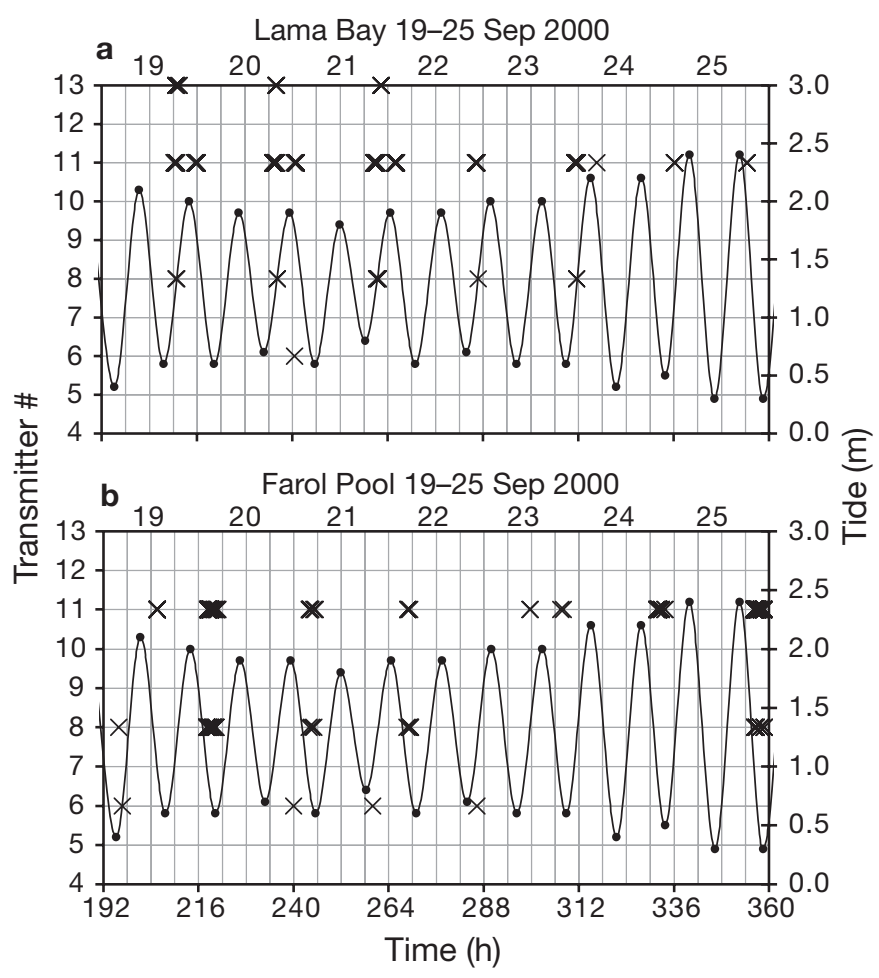

Fig. 3. Negaprion brevirostris. Record of acoustic signals from transmitters carried by Sharks 5 to 13 in September 2000. Each data point $(x)$ represents an individual detection for 1 of 8 sharks in real time (Time $0=$ initial deployment of receiver array) over a $7 \mathrm{~d}$ period. Presence of sharks during different phases of the tidal cycle are shown for 2 locations: (a) Lama Bay, the entrance of the tidal creek, where the majority of detections occurred during rising and falling tides on either side of peak high tide; (b) Farol Pool, a small pool on the reef flat in front of Farol Island, where the majority of detections occurred during low tide. Refer to Fig. 1 for locations

detections were recorded. However, receiver data suggest that at least some sharks moved to locations farther from Lama Bay at low tide than was observed during March 2000. For example, on 4 occasions during low tide, these sharks were detected at a more distant reef-flat tide pool (Nine Pool) east of Farol Island. These sharks were also recorded during low tide in a large tide pool (Cemetery Pool) located west of Cemetery Island (see Fig. 1). During March, sharks were never detected on the receiver at Nine Pool, and were only twice detected on receivers in Cemetery Pool during low tide.

Sharks in the second group, originally captured in shallow water on the reef flats south of Cemetery Island at low tide, were subsequently located on these same flats and within Cemetery Pool during high tide (52 of 75 high-tide detections), but they also moved to Lama Bay at high tide (they were detected on the Lama Bay receiver during 13 separate high tides). Sharks were detected in Cemetery Pool on 6 occasions during 


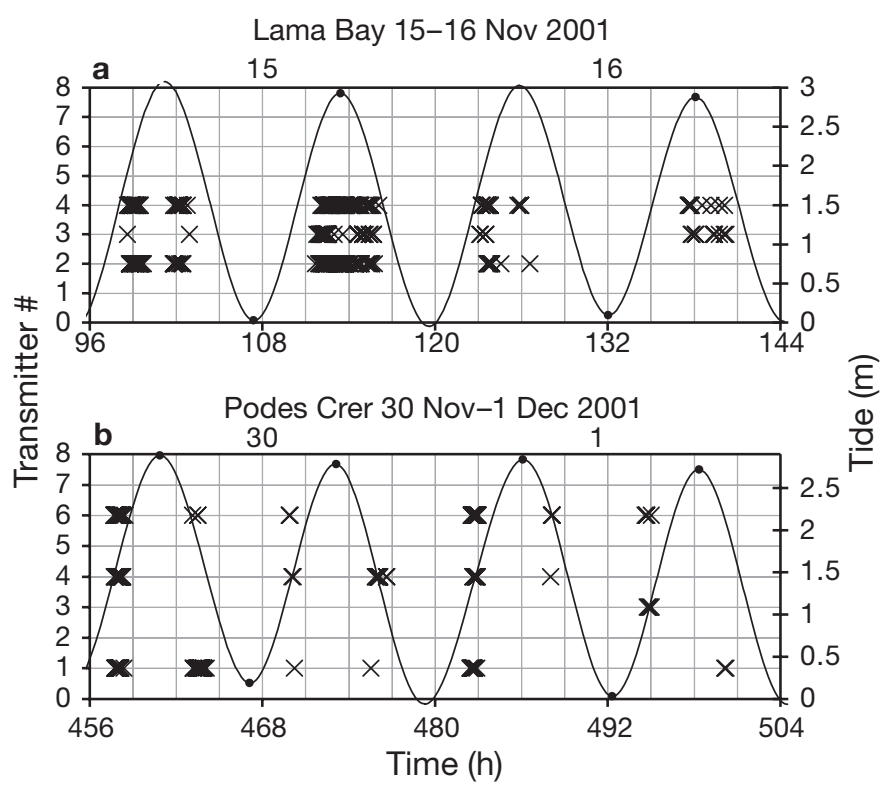

Fig. 4. Negaprion brevirostris. Record of acoustic signals from transmitters carried by Sharks 1 to 8 in November 2001. Each data point $(x)$ represents an individual detection for 1 of 7 sharks in real time (Time $0=$ initial deployment of receiver array) over a $2 \mathrm{~d}$ period. Presence of sharks during different phases of the tidal cycle are shown for 2 locations: (a) Lama Bay, the entrance of the tidal creek, where the majority of detections occurred during rising and falling tides on either side of peak high tide; (b) Podes Crer, a shallow inlet directly connected to the open ocean located along the southern periphery of the atoll. Refer to Fig. 1 for more detail on locations

low tide. However, these sharks moved relatively far from the Cemetery flats during other low tides, and were recorded at Farol Pool (5 times), Barretinha Pool (5 times) and Nine Pool (once) at low tide.

\section{November 2001}

In November, very few lemon sharks were observed at locations where they had been observed and easily captured on previous trips (Farol and Barretinha pools at low tide, and Lama Bay during high tide). Only 1 shark was captured in Lama Bay and 1 shark in Farol Pool during the entire trip (Table 2). Several sharks were captured on the shallow flats south of Cemetery Island, and several were captured in larger pools (Jupiter Pool and Podes Crer) in the southern part of the atoll (see Fig. 1). The small shark captured in Farol Pool was presumed to be young-of-the-year (approximately 9 mo old), whereas all other sharks would have been born the previous year and were therefore approaching $2 \mathrm{yr}$ in age.

The sharks monitored during November exhibited movement patterns similar to those of sharks observed during the 2 previous trips in terms of repeated visits to specific sites during both low and high tides. Unlike the 2 previous trips, Lama Bay did not figure prominently as a high-tide refuge site; however, detections at the mouth of Lama Bay near high tide were still fairly common (22 of 60 high tide detections). During high tide, several sharks moved to the receiver in Lama Bay from a variety of low-tide locations, including Cemetery and Jupiter pools (Fig. 4a). Sharks were most frequently detected during high tide on the flats south of Cemetery Island (27 of 60 high tide detections) and in Cemetery Pool (11 detections).

Detections during low tide on the November trip were restricted to larger pools in the interior of the atoll, including Cemetery Pool (24 detections) and Jupiter Pool (9 detections). Podes Crer also appears to have been used by sharks during low tide. Although no receiver was placed directly in Podes Crer, a receiver stationed adjacent to the pool detected sharks on 40 occasions during either rising or falling tide, and several sharks repeatedly moved past this receiver, suggesting that they were detected on their way to and from the Podes Crer pool where they were presumably located during low tide (Fig. 4b).

\section{DISCUSSION}

The extreme tidal range and the remoteness of Atol das Rocas precluded the continuous use of boats or active tracking to determine activity patterns of young lemon sharks. In addition, sharks were most commonly observed in shallow water or isolated tide pools, which were inaccessible to a boat at low tide. During high tide, active tracking would have been extremely difficult owing to the strong tidal currents and consequent limit on the speed at which a small tracking vessel could have traveled. Therefore, the use of stationary automated receivers to monitor movements of lemon sharks at Atol das Rocas was the most suitable methodology for our study. Similar arrays of stationary receivers have been used to record spatial and temporal use of shark nurseries or other specific fish habitat (Arendt et al. 2001, Heupel \& Hueter 2001) and for estimating the mortality of individuals being monitored (Heupel \& Simpfendorfer 2002).

Owing to the patterns of movement of sharks and the physical layout of Atol das Rocas, coverage of the entire atoll with receivers and instrumentation of large numbers of lemon sharks with transmitters was not feasible given the resources available. The array of automated receivers allowed coverage of only limited sections of Atol das Rocas, and at times resulted in large temporal gaps in location data for individual sharks. Despite these limitations, more than $80 \%$ of 
sharks carrying transmitters were detected at least 100 times during this study, and the array of receivers ultimately generated over 13000 hits upon which to base inferences on activity and movement patterns. In March 2000, a number of individual sharks were detected almost continuously as they moved back and forth between Lama Bay and the nearby reef-flat tide pools. During the 2 later trips, young lemon sharks exhibited far less site attachment to these locations and moved greater distances within the atoll. However, there were still numerous detections of sharks at high and low tides that indicated their location during tidal extremes in Atol das Rocas. The telemetry data collected in our study, in addition to visual observations made during continual surveys of large areas during each of $60 \mathrm{~d}$ at Atol das Rocas, suggest that as lemon sharks grow, they expand their activities from limited short-distance movements between nearby high and low tide refuge areas when they are first born, to activity spaces that encompass much of the atoll by the end of their first year of life.

During March 2000, lemon sharks demonstrated repeated and predictable behavior, moving between Lama Bay at high tide and the small tide pools on the reef flats in front of Farol Island at low tide. The short distance between these 2 locations allowed sharks to quickly move from one site to the other, resulting in the vast majority of detections occurring during either high or low tide in relatively shallow and isolated locations. The young sharks monitored during March therefore spent the majority of time within 2 refuge areas, where encounters with predators would be expected to be relatively rare. We commonly observed large lemon sharks in large pools connected to the open ocean at low tide, and at locations throughout much of the interior of the atoll during high tide. However, large sharks were never observed in the small reef-flat tide pools during low tides and were rarely observed or captured inside Lama Bay at high tide. In this and related studies (Oliveira 2001, Freitas et al. 2006), only 1 lemon shark of the several hundred captured in Lama Bay was over $200 \mathrm{~cm} \mathrm{TL}$, and only 3 sharks over $150 \mathrm{~cm}$ were captured here. Small lemon sharks venturing out of these refuge habitats face a greater risk of predation, because cannibalism among lemon sharks is common (Vorenberg 1962, Wetherbee et al. 1990, S. Gruber pers. obs.).

During September 2000, 6 mo after the first trip in March, sharks continued to use Lama Bay at high tide and Farol and Barretinha pools at low tide; however, the pattern of movement was far less predictable than during the March trip. Sharks captured on shallow flats south of Cemetery Island showed movements that were oriented around the relatively large Cemetery Pool and shallow flats near Cemetery Island, with the majority of the high-tide detections of these sharks recorded at these 2 sites (Fig. 1). These sharks were infrequently detected during low tides, but they were observed most often in isolated pools at low tide. Sharks moved into Cemetery Pool in addition to Lama Bay during high tide, and several sharks moved between Cemetery Pool or Lama Bay during high tide and Cemetery flats or reef tide pools during low tide. These movements contrast with movement patterns observed in March, which was characterized by long periods of almost constant contact with sharks in the tide pools and Lama Bay and few detections at any other locations during high or low tide-i.e. by a regular pattern of movement between 2 refuge locations located a short distance from one another.

During the third trip 13 mo later in November 2001, sharks were still detected in Lama Bay during high tide, albeit less frequently than during the 2 earlier trips. In November, sharks rarely occurred in the small reef-flat tide pools during low tide. Use of Cemetery Pool and the shallow flats near Cemetery Island increased during high tide, and sharks often occupied 2 large pools (Jupiter and Podes Crer) near the southern boundary of the atoll during low tide. Based on visual surveys of these pools at low tide during the previous 2 trips, these pools did not appear to be commonly used by younger and smaller lemon sharks earlier in the year. Sharks continued to remain in relatively shallow water near Farol and Cemetery islands during high tide, and also continued to occupy shallow water during low tide in Cemetery Pool, Jupiter Pool and most likely Podes Crer. Thus, even though sharks tracked in November traversed a much larger area and covered a large portion of the atoll, the same general trend of movement was observed during all 3 trips. That is, lemon sharks largely restricted their movements to shallow water during both low and high tides.

Because habitat use and movement patterns have been extensively studied at other nursery locations, there is a fair body of knowledge for comparison with habitat use of lemon sharks at the Atol das Rocas nursery. Young lemon sharks at Atol das Rocas demonstrated a high degree of site attachment, particularly during the first few months of their lives when movements were very predictable and occurred within a very limited portion of the atoll, and their movements were effectively restricted to shallow water and isolated refuge locations. The sharks expanded their movements as they grew, and appeared to occupy large portions of the atoll with a continued concentration of activity in shallow water during high and low tidal extremes. Morrissey \& Gruber (1993a) found that juvenile lemon sharks at Bimini, the Bahamas, displayed a high degree of site attachment and made 
repeated movements within consistent near-shore, shallow locations. Sharks at Bimini frequently revisited preferred areas and persisted in well-defined locations, limiting their movements to within about $5 \%$ of the available shoreline area. These sharks made infrequent long-distance movements away from high activity areas, and were thought to sometimes make day-today shifts between foraging sites within their home range. Morrissey \& Gruber (1993b) found that lemon sharks spent $75 \%$ of their time in water less than $50 \mathrm{~cm}$ deep, and demonstrated a strong preference for shallow water. Lemon sharks in the Bimini nursery rarely ventured from the mangrove shoreline; in fact, they often penetrated the mangroves to swim in, or lie on the bottom among, the mangrove roots. Morrissey \& Gruber (1993b) concluded that lemon sharks occupying the Bimini nursery avoided predation by confining their activities to water depths too shallow for most predators. Based on our observations at Atol das Rocas and on the studies conducted by Morrissey \& Gruber, repeated and predictable movement patterns, a high degree of site fidelity, and almost exclusive occupation of shallow habitat appear to be general characteristics of the behavior of newborn lemon sharks on their nursery grounds. The likely selective factor favoring this type of behavior is predator avoidance. The idea that young lemon sharks select shallow nurseries for increased protection from predators was posed long ago (Springer 1950). Our observations at Atol das Rocas suggest that lemon sharks expand their home range and activity space as they age, which is in agreement with studies on movement patterns and habitat use of various-sized lemon sharks on their nursery grounds in Bimini, the Bahamas (Morrissey \& Gruber 1993a, Sundstrom et al. 2001).

Because lemon sharks have relatively few young (up to 18 biennially) and grow slowly in comparison with many species of sharks, adequate survival is imperative for stable populations (Brown \& Gruber 1988, Gruber et al. 2001). Even with a high degree of site fidelity and movements largely restricted to shallow water, lemon sharks suffer a high natural mortality, with estimates of annual mortality at Bimini between 40 and $50 \%$ in the first year (Manire \& Gruber 1993, Gruber et al. 2001). Mortality of lemon sharks at Atol das Rocas also appears to be high, as might be expected for young sharks trying to survive in a nursery that offers limited refuge areas in proximity to areas frequented by large predatory sharks (Freitas et al. 2006). Although the Atol das Rocas nursery may be considered to be poorer in quality than a location such as Bimini (owing to the more limited refuge habitat and presence of large predators at Atol das Rocas), lemon sharks apparently grow at a substantially faster rate at Atol das Rocas than at Bimini (Freitas et al. 2006). There- fore, Atol das Rocas may be a relatively high-quality nursery in terms of food availability, or rapid growth may be associated with more limited refuge habitat. Habitat selection is clearly a function of a multitude of interacting variables, both physical and biological, among those being access to an adequate food supply and protection from predation (Gruber et al. 2001).

A number of studies have found a relationship between the activity patterns of lemon sharks and time of day (Gruber et al. 1988, Correia et al. 1995, Sundstrom et al. 2001). However, such diel movement patterns appear to apply to larger sharks over $120 \mathrm{~cm}$, which are less dependent upon shallow water and isolated locations for protection from predators. As evidenced by the considerable telemetry data at both Bimini and Atol das Rocas, the movements of newborn and young lemon sharks appear to revolve around predator avoidance and the advantage of shallow water for lower risk of predation-stay shallow and stay alive. Movements of small sharks at Atol das Rocas are influenced tremendously by the tidal cycle, and time of day appears to have little relevance for survival.

Physical characteristics of the environment determine where an organism can survive and reproduce successfully, and define the geographical distribution of that organism (Ricklefs \& Miller 2000). Despite the lack of mangrove and seagrass habitat typical of other nursery areas and the presence of a large tidal range at Atol das Rocas, young lemon sharks are able to survive by restricting their activities to an isolated tidal creek, small pools and other shallow water locations where there are few predators. Although the behavior of lemon sharks at Atol das Rocas differs from behavior at other nursery locations, these sharks presumably achieve the same end result of enhanced survival owing to reduced predation. Our study on the movement patterns of young lemon sharks at Atol das Rocas demonstrates obvious differences among lemon sharks occupying nurseries with variable physical characteristics, and implies that other life-history characteristics such as growth, maturity, survival and ultimately reproductive success or evolutionary fitness may also vary substantially among individuals that occupy nursery areas with varying environmental characteristics.

Acknowledgements. We are indebted to M. de Brito Silva and IBAMA for access to the REBIO Atol das Rocas; to the National Science Foundation (NSF) and CNPq for supporting the 1999-2001 international cooperative program; to the National Geographic Society for financial support for several expeditions; to Captain J. Seiler and R/V 'Seward Johnson' crew for their support of 1999-2000 field work; to Projeto Tamar, Fundação Pró-Tamar, Captain Z. Jost, T. DiGirolamo, C. Butron, A. Castro, M. Drake and C. Marquette for their assistance in the field; to B. Franks for help with an earlier version of this manuscript; and to A. Wood for help with figures. 


\section{LITERATURE CITED}

Arendt MD, Lucy JA, Evans DA (2001) Diel and seasonal activity patterns of adult tautog, Tautoga onitis, in lower Chesapeake Bay, inferred from ultrasonic telemetry. Environ Biol Fish 62:379-391

Brown CA, Gruber SH (1988) Age assessment of the lemon shark, Negaprion brevirostris, using tetracycline validated vertebral centra. Copeia 1988:747-753

Castro JI (1993) The shark nursery of Bulls Bay, South Carolina, with a review of the shark nurseries of the southeastern coast of the United States. Environ Biol Fish 38:37-48

Correia J, DeMarignac J, Gruber SH (1995) Young lemon shark behavior in Bimini Lagoon. Bahamas J Sci 3:1-7

Feldheim KA, Gruber SH, Ashley MV (2002) The breeding biology of lemon sharks at a tropical nursery lagoon. Proc R Soc Lond B 269:1655-1661

Freitas RHA, Rosa RS, Gruber SH, Wetherbee BM (2006) Early growth and juvenile population structure of lemon sharks Negaprion brevirostris, in the Atol das Rocas Biological Reserve, off north-east Brazil. J Fish Biol 68: 1319-1332

Gruber SH (1982) Role of the lemon shark, Negaprion brevirostris (Poey) as a predator in the tropical marine environment: a multidisciplinary study. Fla Sci 45:46-75

Gruber SH, Nelson DR, Morrissey JF (1988) Patterns of activity and space utilization of lemon sharks, Negaprion brevirostris, in a shallow Bahamian lagoon. Bull Mar Sci 43: $61-76$

Gruber SH, de Marignac JRC, Hoenig JM (2001) Survival of juvenile lemon sharks at Bimini, Bahamas, estimated by mark-depletion experiments. Trans Am Fish Soc 130: 376-384

Heupel MR, Hueter RE (2001) Use of an automated acoustic telemetry system to passively track juvenile blacktip shark movements. In: Sibert JR, Nielson JL (eds) Electronic tagging and tracking in marine fisheries. Kluwer Academic, Dordrecht, p 217-236

Heupel MR, Simpfendorfer CA (2002) Estimation of mortality of juvenile blacktip sharks, Carcharhinus limbatus, within a nursery area using telemetry data. Can J Fish Aquat Sci 59:624-632

Manire CA, Gruber SH (1993) A preliminary estimate of natural mortality of age-0 lemon sharks, Negaprion brevirostris. NOAA Tech Rep NMFS 115:65-71

Morrissey JF, Gruber SH (1993a) Home range of juvenile lemon sharks, Negaprion brevirostris. Copeia 1993: 425-434

Editorial responsibility: Kenneth Sherman (Contributing Editor), Narragansett, Rhode Island, USA
Morrissey JF, Gruber SH (1993b) Habitat selection by juvenile lemon sharks, Negaprion brevirostris. Environ Biol Fish 38:311-319

Oliveira PGV (2001) Levantamento da fauna de elasmobrânquios e estudo da biologia comportamental do tubarão limão, Negaprion brevirostris (Poey, 1868), tubarão lixa, Ginglymostoma cirratum (Bonnaterre, 1788) na Reserva Biológica do Atol das Rocas, RN-Brasil. MS thesis, Universidade Federal de Pernambuco, Recife

Ricklefs RE, Miller GL (2000) Ecology. WH Freeman, New York

Rosa RS, Moura RL (1997) Visual assessment of reef fish community structure in the Atol das Rocas Biological Reserve, off Northeastern Brazil. Proc 8th Int Coral Reef Symp 1: 983-986

Silva MB, Campos CEC, Targino SG (2002) Atol das Rocas: primeira unidade de conservação marinha do Brasil e único atol do Atlântico sul. Ger Cost Int 2:27-28

Simpfendorfer CA, Milward ME (1993) Utilisation of a tropical bay as a nursery area by sharks of the families Carcharhinidae and Sphyrnidae. Environ Biol Fish 37: $337-345$

Springer S (1950) Natural history notes on the lemon shark, Negaprion brevirostris. Texas J Sci 2:349-359

Stiling P (2002) Ecology. Prentice Hall, Upper Saddle River, NJ

Sundstrom LF, Gruber SH (1998) Using speed-sensing transmitters to construct a bioenergetic model for subadult lemon sharks, Negaprion brevirostris (Poey), in the field. Hydrobiologia 371/372:241-247

Sundstrom LF, Gruber SH, Clermont SM, Correira JPS and 5 others (2001) Review of elasmobranch behavioral studies using ultrasonic telemetry with special reference to the lemon shark, Negaprion brevirostris, around Bimini Islands, Bahamas. Environ Biol Fish 60:225-250

Voegeli FA, Smale MJ, Webber DM, Andrade Y, O'Dor RK (2001) Ultrasonic telemetry, tracking and automated monitoring technology for sharks. Environ Biol Fish 60: 267-281

Vorenberg MM (1962) Cannibalistic tendencies of lemon and bull sharks. Copeia 1962:455-456

Wagner GN, Stevens ED, Byrne P (2000) Effects of suture type and patterns on surgical wound healing in rainbow trout. Trans Am Fish Soc 129:1196-1205

Wetherbee BM, Gruber SH, Cortes E (1990) Diet, feeding habits, digestion and consumption in sharks, with special reference to the lemon shark, Negaprion brevirostris. NOAA Tech Rep NMFS 90:29-47

Submitted: July 8, 2005; Accepted: February 5, 2007

Proofs received from author(s): July 24, 2007 